\title{
Efektivitas Konseling Kelompok Dengan Teknik Cognitive Restructuring (CR) Untuk Menurunkan Perilaku Bullying Pada Siswa SMP Plus Nurul Hikmah Pamekasan
}

\author{
Iswatun Hasanah \\ Fakultas Psikologi Universitas 17 Agustus 1945 Surabaya \\ Email: i2s_chasanah@yahoo.co.id
}

\begin{abstract}
:
The purpose of this research is to know effectiveness of group counseling by using "cognitive restructuring" technique to reduce "bullying" habit of the students of SMP Plus Nurul Hikmah Pamekasan. The subject of this research is the students of SMP Plus Nurul Hikmah Pamekasan which is showing "bullying” Habit $(N=6)$. The kind o the research that is used quasi experiment designed in One Group pretest posttest design, it is an experiment that conducted only to one group without compared group whit bullying scale as data collection instrument arranged by researcher based on theory and has been tested for its validity and reliability. Data analysis that is used in this research is statistic test wilcoxon and the result of this research that is done analyzed by using statistic test wilcoxon by value asymp sig=0,046 (coefficient level $P<0,05$ ) and $Z$ arithmetic $=1,997$ could be concluded that a group counseling by using cognitive restructuring is effective to reduce bullying habit of SMP Plus Nurul Hikmah Pamekasan.
\end{abstract}

Keyword: Group Counseling, Cognitive Restructuring Technique, Bullying

Received February 05, 2018; Revised March 07, 2018; Accepted April 01, 2018

How to Cite: Hasanah I. (2018). Efektivitas Konseling Kelompok Dengan Teknik Cognitive Restructuring (CR) Untuk Menurunkan Perilaku Bullying Pada Siswa SMP Plus Nurul Hikmah Pamekasan. JKI (Jurnal Konseling Indonesia), 3(2), 42-47.

\section{PENDAHULUAN}

Menurut, bullying adalah sebuah situasi di mana terjadinya penyalagunaan kekuatan/kekuasaan yang dilakukan oleh seseorang/kelompok. Pihak yang kuat di sini tidak hanya berarti kuat dalam ukuran fisik, tetapi bisa juga kuat secara mental, dalam hal ini sang korban bullying tidak mampu membela atau mempertahankan dirinya karena lemah secara fisik atau mental.

Hal ini tidak jauh berbeda disampaikan oleh Coloroso (Ningrum, 2011) yang mendefinisikan bullying "Penindasan atau Kekerasan" adalah tentang penghinaan yaitu suatu perasaan tidak suka yang sangat kuat terhadap seseorang yang dianggap tidak berharga, inferior, atau tidak layak mendapat penghargaan. Fenomena bullying tersebut menjadi satu mata rantai yang tidak terputus. 
Setiap generasi akan memperlakukan hal yang sama untuk merespon kondisi situasional sekolah yang membuatnya tertekan, sehingga pola perilaku yang diwariskan ini akan menjadi perilaku kekerasan. Seperti yang disampaikan oleh (Astuti, 2008) bahwa senioritas sebagai salah satu perilaku bullying, seringkali justru diperluas oleh oleh siswa sendiri sebagai kejadian yang bersifat laten. Senioritas dilanjutkan untuk hiburan, penyaluran dendam, iri hati, atau mencari popularitas, melanjutkan tradisi atau untuk menunjukkan kekuasaan. Hasil penelitian yang dilakukan oleh (Simbolon, 2012) menyatakan bahwa faktor penyebab perilaku bullying adalah senioritas, meniru, serta karena pengalaman masa lalu.

Bullying dapat dilakukan oleh remaja kepada teman sebayanya atau yang usianya lebih muda atau oleh orang dewasa pada orang yang lebih muda. Bentuk bullying yang biasanya terjadi adalah mengolok-olok, meminta uang (memalak), menyakiti secara fisik (menampar, memukul, mencubit) atau mengancam dengan kata-kata baik secara verbal maupun nonverbal, selain itu terdapat juga bullying yang dilakukan di media sosial, yaitu kekerasan melalui internet yang dikenal dengan sebutan cyber-bullying. Bentuk bullying yang terakhir ini adalah berupa mem-posting-kan komentar yang menyerang secara psikis pada si pemilik blog, $e$ mail, facebook, twitter atau produk layanan internet lainnya.

Bullying verbal adalah jenis bullying yang seringkali terjadi dan dilakukan oleh siswa. Berdasarkan hasil pengamatan yang dilakukan di SMP Plus Nurul Hikmah Pamekasan, jenis bullying yang sering terjadi adalah bullying verbal. Hasil penelitian yang dilakukan oleh (Darmawan, n.d.) juga menemukan bahwa kurang dari 50\% subjek penelitian yang sering dan selalu melakukan bullying, dan bentuk bullying verbal adalah yang paling sering dilakukan dan meskipun dalam prosentase yang kecil bullying juga berdampak terhdap kecenderungan depresi pada remaja, dimana depresi tersebut brakibat adanya pikiran untuk melakukan bunuh diri dan melukai diri.

Dalam kasus bullying ini, setidaknya ada 3 elemen yang terlibat, yaitu pelaku (the bully), korban (victim) dan penonton (by stander). Pelaku biasanya adalah orang yang lebih kuat, baik secara fisik maupun memiliki pengaruh di lingkungan tersebut baik berjenis kelamin laki-laki maupun perempuan. Korban biasanya orang yang lemah, tak berdaya dan tidak bisa berbuat apa-apa saat disakiti. Penonton adalah orang yang ada di tempat kejadian, baik teman si korban atau justru teman pelaku yang meskipun tidak ikut melakukan bullying namun ikut menyaksikan. Kuatnya pengaruh pelaku membuat penonton yang berposisi sebagai saksi menjadi bungkam dan tidak berani melaporkan kejadian yang dilihatnya. Selain itu tekanan psikologis yang diberikan pelaku (mengancam akan berbuat lebih jahat jika ia melapor) membuat korban menjadi tertutup.

Penanganan terhadap kasus bullying perlu mendapat perhatian serius sebagai bentuk perlindungan terhadap anak-anak yang merujuk pada Undang-Undang Perlindungan Anak No. 23 tahun 2003 pasal : 4 yang berbunyi "Setiap anak berhak untuk dapat hidup, tumbuh, berkembang, dan berpartisipasi secara wajar sesuai dengan harkat dan martabat kemanusiaan, serta mendapat perlindungan dari kekerasan dan diskriminasi” (KUNSIANG, 2017). Hak untuk terbebas dari segala bentuk tekanan, kekerasan dan perlakuan tidak layak adalah milik semua anak Indonesia.

Efek yang ditimbulkan dari tindakan bullying verbal yakni menciderai psikis korban, yaitu dapat mengakibatkan perasaan harga diri yang rendah, perasaan terhina dan malu, selain itu dapat pula memunculkan perasaan marah karena diperlakukan tidak adil yang dapat memicu tindakan balas dendam, atau ketakutan berkepanjangan (trauma) (Yandri, 2014).

Pelaku bullying verbal memiliki pola pikir dan anggapan yang tidak logis, sehingga pelaku bullying verbal dapat melakukan tindak kekerasan yang berulang-ulang kepada korban, oleh sebab itu pentingnya reorganisasi pikiran pada akhirnya akan menghasilkan reorganisasi perilaku pada pelaku bullying verbal. Berdasarkan karakteristik pelaku bullying verbal, Cognitive Restructuring merupakan suatu cara yang tepat untuk menurunkan tindak kekerasan/ perilaku bullying verbal. Cognitive Restructuring adalah teknik konseling yang dapat mengubah dan mengganti kepercayaan yang negatif/ tidak logis menjadi kepercayaan yang lebih realistik / masuk akal (Nursalim, 2013). Menurut (Cormier, Nurius, \& Osborn, 2016) bahwa strategi Cognitive Restructuirng/ CR adalah strategi untuk membantu Klien untuk menetapkan hubungan antara persepsi dan kognisinya dengan emosi dan perilakunya, dan untuk mengidentifikasi persepsi atau kognisi yang salah/ merusak diri, dan mengganti persepsi / kognisi tersebut dengan yang lebih meningkatkan diri. Menurut (Martin \& Pear, 2015), asumsi dari teori kognitif yakni; (1) individu menginterpretasi dan bereaksi terhadap kejadian-kejadian dengan membentuk kognisi-kognisi, keyakinan, harapan, sikap, berdasarkan pemahaman tentang kejadian-kejadian tersebut; dan (2) kognisi yang cacat atau maladaptif dapat menyebabkan gangguan emosi dan perilaku.

Berdasarkan Asumsi teori kognitif tersebut tampak bahwa kekeliruan berfikir pada akhirnya akan menyebabkan masalah emosi dan perilaku, seperti halnya pada perilaku bullying verbal. Adapun Strategi Cognitive Restructuring ini akan diterapkan dalam bentuk Konseling kelompok, agar para pelaku bullying 
verbal dapat saling memberi dorongan dan motivasi kepada individu yang lainnya untuk membuat perubahan-perubahan dan memanfaatkan potensi dirinya secara maksimal.

\section{METODE PENELITIAN}

\section{Subjek}

Subjek penelitian yaitu siswa kelas 7 dan 8 adalah rekomendasi dan permintaan dari pihak sekolah yang diambil berdasarkan hasil laporan dari buku pribadi siswa yang menjadi bukti catatan perilaku dan kasus siswa, dari catatan tersebut diperoleh informasi siswa yang sering membully teman-temannya. Siswa yang direkomendasikan oleh pihak sekolah untuk mendapatkan treatment sebanyak 6 siswa, dan kemudian siswa tersebut diberikan skala pre test untuk melihat kondisi awal subjek penelitian, dan ternyata hasilnya 6 siswa tersebut perilaku bullyingnya berada pada kategori tinggi sekali dan tinggi.

Adapun nilai pre test subjek penelitian tercantum dalam tabel dibawah ini:

Tabel 1. Nilai pre test subjek

\begin{tabular}{cccc}
\hline No & $\begin{array}{c}\text { Subjek } \\
\text { (Inisial) }\end{array}$ & $\begin{array}{c}\text { Nilai pre } \\
\text { test }\end{array}$ & Keterangan \\
\hline 1 & Subjek A & 130 & Tinggi Sekali \\
2 & Subjek B & 130 & Tinggi Sekali \\
3 & Subjek C & 109 & Tinggi \\
4 & Subjek D & 125 & Tinggi Sekali \\
5 & Subjek E & 108 & Tinggi \\
6 & Subjek F & 122 & Tinggi Sekali \\
\hline
\end{tabular}

\section{Prosedur Eksperimen}

Penelitian ini dilaksanakan melalui 3 tahapan, yaitu 1) tahap persiapan, 2) tahap seleksi subjek, 3) tahap pelaksanaan eksperimen. Kegiatan Eksperimen dilaksanakan sebanyak 4 kali pertemuan yakni Pertemuan pertama terdiri dari 3 tahap, yakni tahap 1 (permulaan), tahap II (peralihan), dan tahap ketiga (Kegiatan), pertemuan kedua, pertemuan ketiga, dan pertemuan terakhir termasuk didalamnya berisi kegiatan tahap pengakhiran. Adapun Masing-masing pertemuan berdurasi waktu antara 60 menit - 120 menit (maksimal).

\section{Teknik Analisa Data}

Teknik analisa data yang dgunakan dalam penelitian ini adalah analisa data statistika non parametrik wilcoxon karena subjek penelitian sebanyak 6 siswa yang menunjukkan perilaku bullying. Analisa data dengan menggunakan teknik wilcoxon digunakan untuk menguji beda skor dari dua sampel yang berpasangan (related sample),yaitu untuk melihat apakah ada perubahan perilaku bullying pada saat pre test dengan post test. Analisis data statistik menggunakan bantuan SPSS versi 20.0.

\section{HASIL}

Tabel 2. Data skor subjek penelitian

\begin{tabular}{ccccccc}
\hline No & $\begin{array}{c}\text { Nama } \\
\text { Subjek }\end{array}$ & Pre test & Kategori & Post test & Kategori & Keterangan \\
\hline $\mathbf{1}$ & Subjek A & 130 & Tinggi Sekali & 110 & Tinggi & Turun \\
$\mathbf{2}$ & Subjek B & 130 & Tinggi Sekali & 118 & Tinggi & Turun \\
$\mathbf{3}$ & Subjek C & 109 & Tinggi & 114 & Tnggi & Tetap \\
$\mathbf{4}$ & Subjek D & 125 & Tinggi Sekali & 102 & Tinggi & Turun \\
$\mathbf{5}$ & Subjek F & 108 & Tinggi & 98 & Tinggi & Tetap \\
$\mathbf{6}$ & Subjek G & 122 & Tinggi Sekali & 112 & Tinggi & Turun \\
\hline
\end{tabular}


Berdasarkan tabel 2 skor terendah subjek penelitian untuk pre test adalah 109 oleh subjek 5 dan skor tertinggi adalah 130 oleh subjek 1 dan subjek 2, sedangkan untuk posttest skor terendah adalah 98 oleh Subjek 5 dan skor tertinggi adalah 118 oleh Subjek 2. Hasil analisis menunjukkan bahwa terdapat 1 subyek penelitian yang memiliki nilai post test lebih tinggi dari nilai pre test

Hipotesis penelitian atau hipotesis kerja (Ha) adalah teknik cognitive restructuring efektif menurunkan perilaku bullying pada siswa SMP Plus Nurul Hikmah Pamekasan, sedangkan hipotesis nol (Ho) yaitu tidak ada pengaruh teknik cognitive restructuring untuk menurunkan perilaku bullying pada siswa SMP Plus Nurul Hikmah Pamekasan. Hasil pengujian hipotesis dengan menggunakan teknik analisis Wilcoxon dapat dilihat pada tabel 4.3 berikut ini.

Tabel 4.3 Hasil Analisis Wilcoxon

Test Statistics ${ }^{\mathrm{a}}$

POST TEST - PRE TEST

$\mathrm{Z}$

$-1.997^{\mathrm{b}}$

Asymp. Sig. (2-

tailed)

a. Wilcoxon Signed Ranks Test

b. Based on positive ranks.

Berdasarkan hasil analisis statistik Wilcoxon diperoleh nilai asymp sig $=0,046$ dan nilai $\mathrm{Z}=$ $1,997^{\mathrm{b}}$.Hipotesis penelitian (Ha) diterima apabila nilai signifikansi (Sig) $<0.05$ atau nilai $\mathrm{Z}_{\text {hitung }}>\mathrm{Z}_{\text {tabel }}$, dan dari tabel 4.2 diperoleh informasi bahwa nilai signifikansinya 0,046 ( $\mathrm{P}<0,05)$ sedangkan nilai $\mathrm{Z}-1,997>$ 1,645 ( $\mathrm{z}$ tabel dengan taraf signifikansi 5\%).

Hal ini dapat disimpulkan bahwa hipotesis penelitian, sehingga penelitian memperoleh hasil bahwa konseling kelompok dengan teknik cognitive restructuring efektif untuk menurunkan perilaku bullying pada siswa SMP Plus Nurul Hikmah Pamekasan.

\section{PEMBAHASAN}

Verbal Bullying yaitu Bullying dengan menggunakan kata-kata untuk membuat seseorang berada di dalam tekanan dan membuat orang melakukan verbal bullying tersebut menjadi lebih superior (Kompasiana dalam www.kompasiana.com).

Pelaku Bullying memiliki kecenderungan agresif, egois, dan memiliki persepsi yang salah terhadap orang lain dan kondisi sekitarnya. Pelaku Bullying memiliki keyakinan/persepsi yang negatif tersebut lambat laun akan menjadi kepribadian anak, dan menganggap bahwa Bullying hal yang biasa dan dapat dilakukan terhadap teman yang lebih lemah, dan hal ini akan menimbulkan dampak negatif terhadap siswa yang menjadi korban. Pelaku bullying verbal memiliki pola pikir dan anggapan yang tidak logis, sehingga pelaku bullying verbal dapat melakukan tindak kekerasan yang berulang-ulang kepada korban.

Menurut (Cormier et al., 2016) menyatakan bahwa restrukturisasi kognitif berakar pada penghapusan distorsi kognitif atau kesimpulan yang salah, pikiran, keyakinan irasional, dan mengembangkan kognisi baru dengan pola respon yang lebih baik atau sehat.

Menurut (Cormier et al., 2016; Nursalim, 2013) Cognitive Rstructuring/ CR memusatkan perhatian pada upaya mengidentifikasi dan mengubah pernyataan diri negatif dan keyakinan-keyakinan klien yang tidak rasional.

CR menggunakan asumsi bahwa respon-respon perilaku dan emosional yang tidak adaptif dipengaruhi oleh keyakinan, sikap, dan persepsi (kognisi) konseli. Tidak jauh berbeda disaapaikan oleh Matin dan Pear (2015) bahwa Cognitive Restructuring adalah strategi untuk mengenali pikiran maladaptif dan menggantinya dengan pikiran yang adaptif, sedangkan menurut hasil penelitian subjek penelitian dapat mengurangi perilaku bullying dengan cara menggantinya dengan pikiran positif/ coping thoughts.

Menurut (Martin \& Pear, 2015) Terapi Kognitif memiliki 2 asumsi teoritis utama (1) individu menginterpretasikan dan bereaksi terhadap kejadian-kejadian dengan membentuk kognisi - kognisi, keyakinan, harapan, sikap, berdasarkan pemahaman tentang pentingnya kejadian - kejadian tersebut; dan (2) kognisi yang cacat atau maladaptif dapat menyebabkan gangguan emosi dan perilaku. Dari asumsi tersebut 
bahwa fokus konseling Cognitive Restructuring adalah mengubah kognisi klien dan kesalahan/kekeliruan dalam berfikir adalah penyebab masalah emosi dan perilaku.

Berdasarkan hasil uji statistik non parametrik wilcoxon dengan asymp sig = 0,046 dan nilai Z hitung $=-1,997$ dapat disimpulkan bahwa konseling kelompok dengan teknik cognitive restructuring efektif untuk menurunkan perilaku bullying pada siswa SMP Plus Nurul Hikmah Pamekasan, walaupun secara perbandingan nilai pre test dan post test terdapat 1 klien yakni subjek 3 yang menunjukkan skor perilaku bullying yang cenderung lebih tinggi, yakni skor pre test 109 dan untuk skor post test 114, secara skor mengalami peningkatan tetapi masih tetap berada di kategori yang sama, yakni kategori tinggi.

Berdasarkan hasil penelaahan terhadap subjek 3 diperoleh informasi, bahwa subjek 3 pada saat mengikuti kegiatan konseling kelompok tidak melakukan tugas rumah, yakni belajar menerapkan CT dalam kondisi yang sebebnarnya, dan selama kegiatan subjek 3 terlihat murung dan pendiam. Penyebab subjek 3 menunjukkan perilaku tersebut, yakni karena subjek 3 memiliki masalah dengan keuarganya, beberapa hari dimarahi karena sikap subjek 3 yang menurut orang tua menunjukkan sikap anak nakal, selain itu subjek 3 merasa tidak nyaman bersama dengan anggota subjek penelitian yang lain, yang rata-rata adalah kakak kelasnya.

Keefektifan konseling kelompok dengan teknik cognitive restructuring untuk menurunkan perilaku bullying khususnya bullying verbal tidak lepas dari keterlaksanaan tahapan-tahapan dalam proses treatment. Tahapan-tahapan dalam kegiatan ini terdiri dari 6 tahapan. Tahapan-tahapan dalam konseling kelompok dengan teknik cognitive restructuring yaitu; (1) Rational: tujuan dan tinjauan singkat prosedur. (2) Identifikasi pikiran klien dalam situasi problem (3) Pengenalan dan latihan coping thought. (4) Pindah dari pikiran-pikiran negative ke coping thoughts (CT). (5) Pengenalan dan latihan penguat positif (6) Tugas rumah dan tindak lanjut. Selain itu, sikap bertanggung jawab dan keinginan berubah dari klien sangat penting untuk keefektifan treatment, mengingat dalam tahapan terdapat kegiatan identifikasi, latihan, dan tugas rumah yang membutuhkan keseriusan dan konsisitensi dari klien dalam pelaksanaan dan penerapannya.

Pada penelitian ini proses pemberian treatment berlangsug selama 4 kali tatap muka/ pertemuan. Pertemuan pertama kegiatan yang dilakukan yaitu proses Attending (penerimaan) kemudian praktikan mengenalkan kegiatan, tujuan umum, prosedur pelaksaaan dan azas-azas konseling. Langkah kegiatan selanjutnya yaitu sharing kesiapan mengikuti kegiatan untuk memastikan kesiapan serta tanggung jawab klien dalam mengikuti kegiatan treatment. Setelah klien siap mengikuti kegiatan maka praktikan memberikan contoh bahasan masalah bullying verbal yang akan dibahas, untuk kemudian klien bergantian mengemukakan masalahnya dan menetapan masalah utama yang akan dibahas pertama.

Praktikan menjelaskan rasional strategi yang akan digunakan. Kegiatan pertama dalam teknik cognitive restructuring yaitu klien mulai mengidentifikasi pikiran-pikiran negatif konseli, yaitu pikiran-pikiran yang sering muncul pada saat dan sedang melakukan perilaku bullying.

Kegiatan pada pertemuan kedua mulai fokus untuk merekonstruksi pikiran - pikiran irrasional klien. Adapun kegiannya yaitu praktikan memberikan pemodelan kaitan antara peristiwa dan emosi yakni pikiran negative terhadap perilaku mem-bully. Kemudian, klien akan mempraktekkannya dalam fikiran bahwa pikiran irrasionalnya yang menyebabkan klien menunjukkan prilaku bullying.

Langkah selanjutnya praktikan mulai mengenalkan pikiran positif (CT)/ atau pikiran menanggulangi. Praktikan menjelaskan mengenai CT dan memberikan contoh CT untuk diterapkan pada saat muncul pikiran irrasional. Setelah klien memahami dan mampu untuk mencetuskan pikiran positif (CT) maka praktikan memberikan tugas rumah untuk mulai memodelkan CT dalam fikiran dan mulai untuk berusaha menerapkannya.

Kegiatan pada pertemuan Ketiga klien sudah memiliki pikiran positif (CT) yang akan digunakan pada saat konseli menghadapi kondisi yang dapat menyebabkan perilaku mem-bullynya muncul. Tahapan dalam kegiatan konseling kelompok dengan teknik cognitive restructuring, implementasi dan internalisasi CT adalah kegiatan yang sangat penting untuk keberhasilan penelitian ini. Klien harus bisa mengimplementasikan CT dalam kondisi yang seringkali dapat menyebabkan mem-bully temannya.

Kegiata yang dilakukan pada pertemuan keempat yaitu klien menceritakan hasil implementasi CT selama 2 hari, kesulitan-kesulitan apa yang ditemui oleh klien selama proses praktek dalam situasi nyata.

Kesulitan-kesulitan yang ditemui oleh klien ditanggapi oleh anggota konseling secara bergantian, Kegiatan keempat adalah kegiatan terakhir, dan kedepan akan ada kegiatan tindak lanjut (follow up) terhadap perilaku klien dalam hal konsistensi implementasi CT dalam menghadapi kondisi-kondisi yang tida ideal dan kondisi yang menyebabkan klien menunjukkan perilaku bullying.

Proses kognitif yang terjadi didalam diri individu seringkali mempunyai implikasi terhadap perubahan tingkah laku. Klien diajak untuk mengenal, mengamati dan memonitor gagasan dan asumsi mereka. Teknik cognitive restructuring adalah proses menemukan dan menilai kognisi seseorang, memahami dampak negatif 


\section{Jurnal Konseling Indonesia}

http://ejournal.unikama.ac.id/index.php/JKI

ISSN: Print 2475-888X - Online 2476-8901

Vol. 3 No. 2, April 2018. hlm. $42-47$

pemikiran tertentu terhadap tingkah laku, dan belajar mengganti kognisi tersebut dengan pemikiran yang lebih realistik dan lebih cocok, jadi untuk perilaku bullying lingkungan dan kondisi korban tidak akan menjdi penyebab munculnya perilaku bullying jika pelaku dapat memiliki pikiran yang rasional tentang dirinya, teman, dan lingkungan sekitarnya. Penelitian ini mendukung penelitian Muthmainnah, 2012. Berjudul Keefektifan Teknik Cognitive Restructuring Untuk Menurunkan Negative Automatic Thoughts (NATs) Pada Siswa SMA, membuktikan bahwa terdapat perubahan pada klien sebelum dan sesudah mendapatkan treatment yakni penurunan NATs.

\section{SIMPULAN DAN SARAN}

Hasil penelitian yang telah dilakukan dan dianalisis dengan uji statistik wilcoxon dengan nilai asymp sig $=0,046(\mathrm{P}<0,05)$ dan $\mathrm{Z}$ hitung $-1,997$ sehingga Hipotesis diterima dan dapat disimpulkan bahwa konseling kelompok dengan teknik cognitive restructuring efektif untuk menurunkan perilaku bullying pada siswa SMP Plus Nurul Hikmah Pamekasan.

\section{DAFTAR RUJUKAN}

Astuti, P. R. (2008). Meredam Bullying: 3 Cara Efektif Mengatasi KPA. Jakarta: PT. Grasindo.

Cormier, S., Nurius, P. S., \& Osborn, C. J. (2016). Interviewing and change strategies for helpers. Nelson Education.

Darmawan, D. (n.d.). Bullying Phenomena In School Setting. Jurnal Kependidikan: Penelitian Inovasi Pembelajaran, 1(2).

KUNSIANG, B. Y. (2017). IMPLIKASI UNDANG-UNDANG PERLINDUNGAN ANAK NO. 23 TAHUN 2002 DITINJAU DARI SUDUT PANDANG PAK DI SMP NEGERI 6 MANADO.

Martin, G., \& Pear, J. (2015). Modifikasi Perilaku Makna dan Penerapannya. Edisi Kesepuluh. Yogyakarta: Pustaka Pelajar.

Ningrum, U. Y. (2011). Perilaku Konsumtif terhadap produk pakaian distro ditinjau dari konformitas pada siswi SMK Abdi Negara Muntilan. Skripsi Program Studi Psikologi Fakultas Ilmu Sosial dan Humaniora Universitas Islam Negeri Sunan Kalijaga Yogyakarta.

Nursalim, M. (2013). Strategi dan intervensi konseling. Jakarta: Akademia Permata.

Simbolon, M. (2012). Perilaku bullying pada mahasiswa berasrama. Jurnal Psikologi, 39(2), $233-243$.

Yandri, H. (2014). Peran Guru BK/Konselor dalam Pencegahan Tindakan Bullying di Sekolah. Jurnal Pelangi, 7(1).

Aditya, S. (2013). Verbal Abuse, Stop Labelling Children!. (Online). Dalam http://www. kompasiana.com. Diakses tanggal 07 April 2017. 